\section{Management and Control Issues for Native, Invasive Species (Reed Canarygrass): Evaluating Philosophical, Management, and Legislative Issues}

\author{
Neil O. Anderson ${ }^{1}$, Alan G. Smith ${ }^{1}$, Andrzej K. Noyszewski ${ }^{1}$, \\ Emi Ito ${ }^{2}$, Diana Dalbotten ${ }^{3}$, and Holly Pellerin ${ }^{3}$
}

ADDITIONAL INDEX WORDS. cryptogenic species, evolution, herbaceous ornamentals, invasion terminology, Phalaris arundinacea

\begin{abstract}
SumMARY. The issue of native invasive species management rarely occurs and is fraught with biological, social, and economic challenges as well as posing difficulties in decision-making for land managers. The terminology for categorization of invasive species is examined in the context of their bias(es), which complicates control. An example of a newly determined native species, which is also invasive, is used as an example to navigate control and regulatory issues. Native, invasive reed canarygrass (Phalaris arundinacea L.) occurs throughout Minnesota and most likely the entire midwest region of central United States and Canadian provinces. The species was previously assumed to be an exotic, nonnative Eurasian import but recent molecular evidence supports its status as a native but invasive species. We address how this change to being a native but highly invasive species modifies approaches to mitigate its potential control for state, Tribal, and local authorities. The implications of these new findings will require differential shifts in land managers' perspectives and approaches for control. Particular differences may exist for Tribal Land Managers vs. departments of natural resources and private agencies. Additionally, regulatory challenges have yet to be decided on how to legislate control for a native invasive species that had been previously assumed as exotic or foreign in origin. These opportunities to change attitudes and implement judicial control measures will serve as a template for other invasive species that are native in origin.
\end{abstract}

$\mathrm{P}$ lant invasions were recognized as an important biological phenomenon more than a century ago (Galatowitsch et al., 1999; Zedler and Kercher, 2005). The modern discipline of invasion biology commenced with the publication of the monograph The Ecology of Invasions by Animals and Plants (Elton, 1958). Although significant scientific research has identified theoretical and causal mechanisms of invasive species spread, biotic and abiotic factors, and land management approaches for their control, invasion biology terminology — often with inherent bias(es) - continues to create confusion in the field.

Part of the bias arose from definitions and views of weeds in cultivated settings, predominantly defining a weed in a judgmental, nonscientific manner as "a plant out of place" (Illinois Industrial University, 1872; Wilson, 1863) that, when it escapes cultivation and establishes self-propagating populations in the wild (Davis et al., 2000; Elton, 1958; Mack et al., 2000), becomes an invasive species. Until recently, the U.S.
Bureau of Land Management (2006) posted "The Weed Hall of Shame." In invasion biology, bias toward a species may arise from determining (sometimes erroneously due to the lack of molecular, genomic tools) whether a species is native or exotic (nonnative) to a continent or specific area of actual or potential invasion. Additional bias(es) may result from implicating spread explicitly based on human-mediated factors and removing humans from species consideration in natural ecosystems. Vague or judgmental terminology helps to perpetuate these bias(es). Since beginning research on invasion biology in 1989, we have found this bias in numerous invasive species with long lag phases from introduction to eventual spread [e.g., purple loosestrife (Lythrum salicaria)], perpetuation of misconceptions regarding the origin of an invasive species [e.g., reed canarygrass (Phalaris arundinacea)], as well as theories of invasive spread. This set the background for seminal papers on invasive species spread by Galatowitsch et al. (1999) and a special issue of Euphytica for plant breeders during crop domestication (Anderson et al., 2006a, 2006b, 2006c).

In this review, we examine implications from an inherent bias on the postulated "exotic" origin of reed canarygrass to exemplify how new scientific findings realigned the origination of midwest U.S. (Minnesota) populations as "native" and thus whether it should be controlled or preserved by land managers, based on potential revised regulatory (legislative) mandates. This may have wide-ranging applicability to other native, invasive plant species.

\section{Invasive species terminology and bias(es)}

Since invasion biology emerged as a science after Elton's monograph (1958), terminology to describe the involved or affected species has gone through an interesting evolution, albeit with occasional inherent bias(es). As mentioned previously, weed science has been fraught with similar bias in judgmental terminology or definitions.

Rawls (1996) describes "burdens of judgment" to explain disagreements that permeate society. A burden encompasses careful consideration of conflicting, complex data because people with divergent backgrounds (such as among invasion biology scientists, land managers, regulators and legislators from varying backgrounds, cultures, and disciplinary foci) have different values, logic, cause and effects, and views of evidence (Frank, 2019). These may cause persistent disagreements in complex fields such as invasion biology. For example, reducing the science of invasion biology to assertions such as "natives are beneficial and exotics are not" overlooks the complexities of species-species interactions and purported

\begin{tabular}{llll}
\hline $\begin{array}{l}\text { Units } \\
\text { To convert U.S. to SI, } \\
\text { multiply by }\end{array}$ & U.S. unit & SI unit & $\begin{array}{l}\text { To convert SI to U.S., } \\
\text { multiply by }\end{array}$ \\
\hline 0.4047 & acre(s) & ha & 2.4711 \\
2.54 & inch $(\mathrm{es})$ & $\mathrm{cm}$ & 0.3937 \\
25.4 & inch $(\mathrm{es})$ & $\mathrm{mm}$ & 0.0394 \\
2.2417 & ton $(\mathrm{s}) / \mathrm{acre}$ & $\mathrm{t} \cdot \mathrm{ha} \mathrm{a}^{-1}$ & 0.4461
\end{tabular}


axiomatic threats of exotic species (Goodenough, 2010). Long (2011) argued these burdens caused disagreements in other scientific disciplines (e.g., climate science), which were "founded in difference rather than error."

Invasive biology terms such as "native" and "nonnative," "exotic," "invaders," or "foreign" denote a human value-added component to their meaning and creates a belief system that invasives "are a unique ecological phenomenon" (Davis and Thompson, 2001). Such restricted views regard native plants as being static or nonspreading outside of their "native" geographic area, whereas "exotic" species spread beyond their intended or cultivated range. Some invasion biologists assert that humans are the sole vector of invasive species that do or can "cause harm," creating definitions of an invasive species as: "A species that a) is nonnative to a specified geographic area, b) was introduced by humans (intentionally or unintentionally), and c) does or can cause environmental or economic harm or harm

Received for publication 11 Jan. 2021. Accepted for publication 15 June 2021.

Published online 28 July 2021

${ }^{1}$ Department of Horticultural Science, University of Minnesota, St. Paul, MN 55108

${ }^{2}$ Department of Earth Sciences, University of Minnesota, Minneapolis, MN 55455

${ }^{3}$ St. Anthony Falls Laboratory, University of Minnesota, Minneapolis, MN 55414

This article was presented as part of the Invasive Plants Research Professional Interest Group workshop entitled "Progress in Identification and Control of Weedy to Invasive Plants both Domestic and Abroad" held on 12 Aug. 2020 during the virtual American Society for Horticultural Science's annual conference.

Funding in support of this publication was from the Minnesota Invasive Terrestrial Plants and Pests Center; the Minnesota Agricultural Experiment Station; Czech-US American Science Information Center (AMVIS); Ministry of Education, Czech Republic, University of South Bohemia in Českě Budějovice; European Union Education for Competitiveness Operational Programme; and the J. William Fulbright Scholar Program.

N.O.A. and A.G.S. are Professors.

A.K.N. is a Postdoctoral Research Associate; currently Quality Control Analyst III, Aldevron, Fargo, ND

E.I. is a Professor and Director of the Limnological Research Center.

D.D. is an Associate Director of Diversity and Broader Impacts.

H.P. is a Research Scientist, Elder, and Instructor.

N.O.A. is the corresponding author. E-mail: ander044@umn.edu.

This is an open access article distributed under the CC BY-NC-ND license (https://creativecommons. org/licenses/by-nc-nd/4.0/).

https://doi.org/10.21273/HORTTECH04796-21 to humans" (Iannone et al., 2020). This overlooks other vectors implicated in the global spread of invasives, such as wind, water, natural disasters, birds, and mammals. In addition to divorcing humans from being a natural species in ecosystems, such terminology may ignore previous evolution of plant communities in ecosystems and that such systems are dynamic and everchanging, such as responding to the effects of climate change. Indeed, in the United Kingdom, about equal numbers of native and nonnative species are expanding their range such that they lack distinguishing characteristics (Davis and Thompson, 2001; Thompson et al., 1995). A positive correlation among exotic and native "species richness" in wetlands was found, wherein exotic invasive species were equally likely to dominate a wetland as native ones, sharing similar negative effects on species biodiversity (Houlahan and Findlay, 2004).

Despite these findings, a native species may be regarded by some to be desirable in cultivated and wild ecosystems, providing essential ecosystem services, whereas an exotic or foreign species may be viewed as undesirable outside of its native range. Of course these static and restrictive definitions are reinforced by research area and/or commodity-based artificial demarcation of "silos of knowledge." Iannone et al. (2020) would classify spreading nonnatives as "nuisance" and/or "established" species exhibiting "range change," but not "invasive" since they are native. The fact remains that plant species spread regardless of political, geographical, or social boundaries via various vectors across time and space, although human-mediated spread by a naturally occurring species, humans (Homo sapiens L.), is a common, but not the only, mode of dispersal.

Resultant vagueness of terminology between "native" and "nonnative" species has been stipulative (Frank, 2019), requiring assumptions that are arbitrary (Chew and Hamilton, 2011; Simberloff, 2012) or subjective to retain flexibility (Colautii and Richardson, 2009). Terminology for the same phenomena was not restricted to these "native" and "nonnative" terms (Davis et al., 2000), since an invasive species could be referred to as: "alien" (Crawley et al., 1996), "colonizer" or "endemic"
(Williamson, 1996), "exotic" (Green, 1997), "imported" (Williamson and Fitter, 1996), “indigenous" (Sauer, 1988), "introduced" (Lonsdale, 1994), "invasive" (Daehler, 1998), "invasive nonindigenous" (Pimentel et al., 2000), "native" (Meyer and Florence, 1996), "naturalized" (Hussey et al., 1992), "nonnative, immigrant" (Bazzaz, 1986), "nonnative, introduced by humans" (Iannone et al., 2020), and/ or "weedy" (Fox, 1990). Definitions of these terms to create a more formalized lexicon of terminology are often debatable (Daehler, 2001; Čuda et al., 2014; Richardson et al., 2000, 2008; Warren, 2007) and recent efforts to clarify them have been questioned (Colautti and Richardson, 2009). For example, the University of Florida Institute of Food and Agricultural Sciences, Invasive Species Council defined seven terms as their lexicon for Floridian invasion biology ("native, nonnative, introduced, established, invasive, nuisance, range change"), while instructing stakeholders to avoid terms such as "native invasive" (replace with "nuisance"), "invasive exotic," "invasive weed," "alien," "foreign," and "indigenous" (Iannone et al., 2020).

Additional connotations with invasive species' terminology outside of the science relate to their impact (Davis and Thompson, 2001). For example, in 1999, U.S. President Bill Clinton issued the landmark Executive Order on Invasive Species (Order 13112, 3 Feb. 1999) wherein an "invasive species' means an alien species whose introduction does or is likely to cause economic or environmental harm or harm to human health." Numerous U.S. federal and state agencies, such as the U.S. Fish and Wildlife Service (2012) and the U.S. Department of Agriculture, Animal and Plant Health Inspection Service (2020), as well as international agencies, such as the European Union (2010) and the International Union for the Conservation of Nature (2021) define invasive species in a similar manner.

Similar to the classic definition of a weed, species dichotomization into distinct classes of "native," "nonnative" invoke normative claims of inalienable rights of native species within their range with an amoral superiority complex (Chew and Hamilton, 2011). Introduction of "nonnative" species 
into a region has been proposed to be "tantamount to trespassing" (Chew and Hamilton, 2011).

Oddly enough, pre-20th-century Europeans viewed introduced species more positively (Frank, 2019), particularly since New World food species such as corn (Zea mays L.), potato (Solanum tuberosum L.), tomato (Solanum lycopersicum L.), and pepper (Capsicum annumm L.) fed the post-Columbian world and were integrated into various cultures worldwide (Weatherfield, 1989). In the United States, there were "acclimatization societies" that introduced Old World species into the continent and the official U.S. government policy supported new PIs until recently (Coates, 2006). It was not until the late 20th century that the realization of detrimental environmental and ecosystem impacts, such as extinction, created regulatory acts, endangered species lists, noxious weed lists, invasive species lists, and gave rise to environmental groups and nongovernmental agencies [NGOs (Frank, 2019)]. In fact, Elton (1958) provided a militaristic view of this as ecological “invasions." In 1964, a monograph was produced by Baker and Stebbins (1965) on the detrimental, evolutionary results of "nonnative" species introductions. Invasion biology came together as a whole in the 1980s, based on articulations by the Scientific Committee on Problems of the Environment (SCOPE) regarding introduced species/environmental properties that create invasive or noninvasive species (Davis, 2006), as well as the dedication by the Organization of Conservation Biology to biodiversity conservation (Soulé, 1985; Takacs, 1996). Most recently, invasion science has been used to encompass biological invasions as a multidisciplinary field including sociology and management (Ricciardi and Cohen, 2007) wherein data from scientists may be directly translated into land management control methods.

Because the focus of this review is to illustrate the challenges and opportunities in decision-making regarding native yet invasive species and their controversial terminology (Anderson et al., 2020a, 2020b), we are not proposing new, less-biased terms for invasive species. Rather, we categorize the dilemmas using standard terminology and their connotations to illustrate the issues for control and management that arise for affected invasion biology interest groups and clientele for species categorized as native, noninvasive; native, invasive; exotic, noninvasive; and exotic, invasive (Table 1). Reed canarygrass is used as the example to illustrate its current status in each category.

\section{Reed canarygrass}

IDENTIFICATION OF NORTH AMERICAN NATIVE VERSUS EXOTIC EUROPEAN. The question naturally arises whether there are qualitative, diagnostic trait (visual trait) differences at the macroscopic and/or microscopic levels that distinguish between North American native and exotic European individuals of reed canarygrass. The standard dichotomous key (which denotes two or more differences for a particular trait to distinguish types) for reed canarygrass separate the species from the others in the genus (Anderson, 1961). The species is characterized as follows: "14. Plants perennial from scaly rhizomes; inflorescence usually more than $5 \mathrm{~cm}$. long, lobed or branched at the base; caryopsis $2.0 \mathrm{~mm}$. long or less, mostly northern hemisphere" (Anderson, 1961). However, within reed canarygrass itself, the only differential traits separate two types, based on leaf coloration, into ribbon grass $[P$. arundinacea f. picta (L.) Arcang; "15. Leaves longitudinally striped with white $4 \mathrm{a}$. ." and reed canarygrass ( $P$. arundinacea f. arundinacea; "15. Leaves uniformly green ...4b.”) (Anderson, 1961). Although minor quantitative variation exists for plant height and biomass, all plants still possess the diagnostic traits, including ligules (Anderson, 1961) and Floret Type 4 (Voshell et al., 2015 ). Thus, there is no differentiation between North American native and exotic European individuals (Akiyama et al., 2015).

Biogeographic origin is integral for risk assessment of PIs (Frank, 2019), although it comes with caveats such as native species may be invasive or cause "harm" and many nonnative species may cause no harm. Genetic markers have recently been found to distinguish among these types. A review of the history leading to this discovery follows. However, land managers cannot use any visual, diagnostic trait to distinguish between native North American types and reed canarygrass of European origin.

Historic Misconceptions LEAD TO BIAs. Reed canarygrass is a cool-season riparian grass with large populations in Europe, Asia, and North America along fresh watercourses (Ambros and Štykar, 1999) and floodplains (Hroudová et al., 2009) growing to water depths of $30 \mathrm{~cm}$. It is also an important commercial crop for forage and has been cultivated as an ornamental perennial since the 18th century (Alway, 1931; Carlson et al., 1996; Casler, 2010; Schoth, 1938), as well as for revegetation (Figiel et al., 1995), shoreline restoration (Figiel et al., 1995), phytoremediation (Chekol et al., 2002), nitrogen removal in wastewater treatment facilities, and for biofuels (Vymazal, 2001, 2013). Reed canarygrass is a predominant forb in central European ecosystems but is viewed as an archaeophyte (predating the Roman Empire) instead of being classified as invasive (Anderson et al., 2016).

Reed canarygrass is a widespread invasive species across the globe (Holm et al., 1991; Kercher and Zedler, 2004). The species predominates in large wetland areas of the United States (Zedler and Kercher, 2004) because it tolerates nutrient fluctuations in riparian environs as well as transportation corridors (Jakubowski et al., 2010) and produces high biomass [4-14 t.ha ${ }^{-1}$ (Čížková et al., 2015; Gyulai et al., 2003)]. Reed canarygrass is the most effective grass species to extract nitrogen from soils and waterways (Marten and Heath, 1985), thus providing ecosystem services in areas with high nutrient levels. Its impact on biodiversity in decreasing native plant species exceeds that of both flowering-rush (Butomus umbellatus L.) and purple loosestrife, other riparian invasives (Lavoie et al., 2003, 2005).

Importation of reed canarygrass by agrarian and horticultural European settlers into North America occurred repeatedly for cultivation as a forage and ornamental crop (Harris, 1835; Lavergne and Molofsky, 2004; New England Farmer, 1834; Schoth, 1938). The extent of spread by the imported reed canarygrass germplasm in extant populations is largely unknown and is in the process of being determined (Noyszewski et al., 2019, 2020, 2021). However, multiple 
Table 1. Potential interest group response options for decision-making, risk assessment, control, and management of four native/invasive and noninvasive/invasive species combinations using current reed canarygrass risk assessments as an example.

\begin{tabular}{|c|c|c|c|c|}
\hline Interest group & Native, noninvasive & Native, invasive & Exotic, noninvasive & Exotic, invasive \\
\hline $\begin{array}{l}\text { Monitoring and } \\
\text { regulatory U.S. } \\
\text { federal agencies }\end{array}$ & $\begin{array}{l}\text { Not listed, unless an } \\
\text { endangered or threatened } \\
\text { species [Convention on } \\
\text { International Trade in } \\
\text { Endangered Species } \\
\text { (CITES)]. } \\
\text { Reed canarygrass is not } \\
\text { endangered or } \\
\text { threatened. } \\
\text { For importation: } \\
\text { enforcement by [U.S. } \\
\text { Department of Agriculture } \\
\text { (USDA), Animal and } \\
\text { Plant Health Inspection } \\
\text { Service (APHIS), Plant } \\
\text { Protection Quarantine } \\
\text { (PPQ)] only if listed. Reed } \\
\text { canarygrass is not listed. }\end{array}$ & $\begin{array}{l}\text { Not categorized; no } \\
\text { listing for reed } \\
\text { canarygrass }\end{array}$ & $\begin{array}{l}\text { If it affects commercial } \\
\text { agriculture and } \\
\text { interstate commerce: } \\
\text { added to noxious } \\
\text { weed lists, import/ } \\
\text { export lists of } \\
\text { allowable species. } \\
\text { Reed canarygrass } \\
\text { not listed. } \\
\text { For importation: } \\
\text { enforcement by } \\
\text { USDA-APHIS-PPQ } \\
\text { only if listed. Reed } \\
\text { canarygrass is not } \\
\text { listed. }\end{array}$ & $\begin{array}{l}\text { If it affects commercial } \\
\text { agriculture and interstate } \\
\text { commerce: added to } \\
\text { noxious weed lists, import/ } \\
\text { export lists of allowable } \\
\text { species. Reed canarygrass } \\
\text { not listed. } \\
\text { For importation: enforcement } \\
\text { by USDA-APHIS-PPQ only } \\
\text { if listed. Reed canarygrass is } \\
\text { not listed }\end{array}$ \\
\hline $\begin{array}{l}\text { Tribal Land } \\
\text { Managers [Great } \\
\text { Lakes Indian } \\
\text { Fish and Wildlife } \\
\text { Commission, } \\
\text { (GLIFWC); i.e., } \\
\text { states } \\
\text { surrounding the } \\
\text { Great Lakes] }\end{array}$ & $\begin{array}{l}\text { Native species models; reed } \\
\text { canarygrass is not listed }\end{array}$ & $\begin{array}{l}\text { Native noninvasive } \\
\text { species models are } \\
\text { not proposed; reed } \\
\text { canarygrass is not } \\
\text { listed }\end{array}$ & $\begin{array}{l}\text { Risk assessment of } \\
\text { invasive species to } \\
\text { Tribal resources: } \\
\text { invasive } \times \text { native co- } \\
\text { occurrence models: } \\
\text { "Quantify the risk of } \\
\text { nonnative invasive } \\
\text { plants to culturally } \\
\text { important native } \\
\text { plants." }\end{array}$ & $\begin{array}{l}\text { Risk assessment of invasive } \\
\text { species to Tribal resources: } \\
\text { Invasive species and invasive } \\
\times \text { native co-occurrence } \\
\text { models: "Quantify the risk } \\
\text { of nonnative invasive plants } \\
\text { to culturally important } \\
\text { native plants"; reed } \\
\text { canarygrass listing as an } \\
\text { exotic, invasive species but } \\
\text { no invasive species model } \\
\text { created }\end{array}$ \\
\hline $\begin{array}{l}\text { Private Land } \\
\text { Managers (State } \\
\text { of Minnesota) }\end{array}$ & $\begin{array}{l}\text { The Nature Conservancy in } \\
\text { Minnesota: protects } \\
\text { native plant communities }\end{array}$ & & & $\begin{array}{l}\text { The Nature Conservancy in } \\
\text { Minnesota: no reed } \\
\text { canarygrass listing }\end{array}$ \\
\hline
\end{tabular}


Table 1. (Continued).

\begin{tabular}{|c|c|c|c|c|}
\hline Interest group & Native, noninvasive & Native, invasive & Exotic, noninvasive & Exotic, invasive \\
\hline $\begin{array}{l}\text { Nongovernmental } \\
\text { organizations } \\
\text { (state of } \\
\text { Minnesota) }\end{array}$ & $\begin{array}{l}\text { Minnesota Native Plant } \\
\text { Society; Restore Your } \\
\text { Shore: Native Plant } \\
\text { Encyclopedia; University } \\
\text { of Minnesota Andersen } \\
\text { Horticulture Library } \\
\text { Plant Information Online } \\
\text { database: includes native, } \\
\text { cultivated species }\end{array}$ & $\begin{array}{l}\text { EEDMapS (Early } \\
\text { Detection and } \\
\text { Distribution Mapping } \\
\text { System) invasive } \\
\text { species: reed } \\
\text { canarygrass listing as: } \\
\text { "Nativity of this plant } \\
\text { is debated; it is native } \\
\text { to Europe and } \\
\text { possibly parts of Asia, } \\
\text { but it may also be } \\
\text { native to NW U.S." }\end{array}$ & $\begin{array}{l}\text { University of Minnesota } \\
\text { Andersen } \\
\text { Horticulture Library } \\
\text { Plant Information } \\
\text { Online database: } \\
\text { includes exotic, } \\
\text { cultivated species }\end{array}$ & $\begin{array}{l}\text { EEDMapS invasive species: } \\
\text { Reed canarygrass listing; } \\
\text { Minnesota Invasive Species } \\
\text { Advisory Council (MISAC): } \\
\text { under guidelines of the } \\
\text { Minnesota State } \\
\text { Management Plan for } \\
\text { Invasive Species }\end{array}$ \\
\hline
\end{tabular}

\footnotetext{
${ }^{\mathrm{z}}$ Monitoring U.S. federal agency listings arise across governmental agencies (not included here are the 50 U.S. states and territories, local or municipal listings; Canadian listings would include the 10 Canadian provinces and three territories and local or municipal listings): the USDA, USDA-APHIS, USDA-APHIS-PPQ, U.S. Army Corps of Engineers, U.S. Bureau of Land Management, U.S. Department of Defense, U.S. Federal Highway Administration, and the U.S. Fisheries and Wildlife Service (see text for specifics).

${ }^{y}$ GLIFWC provides examples of potential responses. Not included here are the separate risk assessment procedures of the 11 Minnesota Tribal Nations: Bois Forte Band of Chippewa, Fond Du Lac Reservation, Grand Portage Band of Chippewa Indians, Leech Lake Band of Ojibwe, Lower Sioux Indian Community, Mille Lacs Band of Ojibwe, Prairie Island Indian Community, Red Lake Band of Chippewa Indians, Shakopee Mdewakanton Sioux (Dakota) Community, Upper Sioux Community, and White Earth Reservation.

${ }^{\mathrm{x}}$ Although the number and type of state agencies with Public Land Managers for invasive species enforcement varies by each U.S. state and Canadian province, in the example State of Minnesota, the involved agencies are MNDNR, MNDA, and MNDOT.
}

reports have surfaced in recent research documenting native North American reed canarygrass populations.

NATIVE AMERICAN USES:

Potential SPREAD OR SPECIES PERPETUATION. Most important to understanding reed canarygrass' native history is the widespread, yet tragically ignored or overlooked, use of this grass by Native American Tribal Nations. Across the North American continent, reed canarygrass was used extensively for weaving, clothing, fishing weirs, basket making, or thatching for wigwam (wickiup, wetu) roofs (Densmore, 1974; Kindscher and Noguera, 2002; Turner et al., 1980). Seeds of related species, maygrass (Phalaris caroliniana Walters) and little seed canarygrass (Phalaris minor Retz.), were also important food sources (Rea, 1991). Collection of leaves for weavings occurred along river edges and trails (Steltzer, 1976). Transport of live plant material and seeds in and among ceded tribal territories throughout the 1800 s along lakes and rivers, which were major transportation corridors until roads and railroads were constructed, may have aided in the spread of reed canarygrass across the continent. Both Native Americans as well as the French and English colonizers connected with the Hudson Bay Company forts in Canada and the United States used these for transportation well into the early 20th century (Newman, 1985).
Cartographic evidence also supports the historic existence of one or more native reeds. For example, some of the earliest maps of Verendrye (circa 1737), Thompson (circa 1814), Long (circa 1823), and Pope (circa 1849) named "Ga-shashagunushkokawi-sibi" or "the-place-of-rushes-river" in Ojibwe for the Roseau River (French for "reed") in Minnesota (Northwest Regional Development Commission, 2014; Prud'homme, 1916). It is unknown which "reedlike" grass this referred to; i.e., reed canarygrass or common reed [Phragmites australia (Cav.) Trin. ex Steud.], both of which are native.

Corollary EVIDENCE OF NATIVE RANGE. Analysis in the 1970s of shoreline reed canarygrass in the Ottawa and French Rivers in Ontario, Canada, as well as the northern Great Lakes, concluded it was native (Dore and McNeill, 1980). Marten and Heath (1985) classified it as "indigenous" to all five continents' temperate climates and later, Merigliano and Lesica (1998) determined populations of the interior western North America were also native. Remote populations in Lake Mistassini and Anticosti Island of Quebec (Lavoie et al., 2005 ) were also postulated to be native. Historic herbaria plant specimens from as early as 1825 matched corsican reed canarygrass $[P$. arundinacea ssp. rotgesii (Husn.) Kerguélen (Merigliano and Lesica, 1998)]. A lack of diagnostic trait(s) as well as molecular marker(s) at that time, which could unequivocally differentiate native vs. European ecotypes (Dore and McNeill, 1980), resulted in reed canarygrass' classification as a cryptogenic species (Carlton, 1996).

Anderson (2019) reported on the discovery of "an unplowed, pristine field (part of the ancient Lake Agassiz lakebed) was used to harvest hay during the Dust Bowl era (1930s) and sold throughout the midwestern U.S." Transport of hay harvested from this native, unplowed field of pure reed canarygrass in the 1930s Dust Bowl era may have enhanced its spread via highway corridors on land, instead of waterways, across the midwestern United States and Canada (Anderson, 2019). Building interstate and interprovincial highways after 1950 increased the area of disturbances along highway corridors and drainage ditches favorable to reed canarygrass to invade (Anderson, 2019). In summation, clearly there are numerous reports of native populations throughout North America predating settlements by European colonizers as well as thereafter. These have been confirmed with more recent genetic evidence that follows.

Genetic EVIDENCE OF ITS NATIVE STATUS. Reviews of early genetic and molecular studies of reed canarygrass (Anderson, 2019; Anderson et al., 2016; Casler and Undersander, 
2006; Noyszewski et al., 2019) provide additional evidentiary support for the species as a North American native. Not surprisingly for individuals within the same species, shared genetic markers among native North American and European individuals were commonly reported for biochemical and molecular nuclear genetic markers. Biochemical markers, such as allozymes or alloenzymes (enzyme forms encoded by different alleles that differ structurally but not functionally from other allozyme alleles at the same genetic locus) showed a high level of similarity among North American and European types (Gifford et al., 2002; Lavergne and Molofsky, 2007); similar findings were reported with single sequence repeats (SSRs) of DNA (Kettenring et al., 2019). Molecular genetic markers showed shared sequences but also genetic differences among continents; e.g., for intersimple sequence repeats of DNA [ISSRs (Anderson et al., 2016)], amplified fragment length polymorphisms [AFLPs (Anderson et al., 2018; Jakubowski et al., 2013)], single nucleotide polymorphisms [SNPs (Noyszewski et al., $2018,2019,2020,2021)]$, as well as internal transcribed spacer regions of the nuclear ribosomal cistron, 18S5.8S-26S [ITS (Graper et al., 2021; Noyszewski et al., 2021; Quintanar et al., 2007; Voshell and Hilu, 2014; Voshell et al., 2011)]. Nelson et al. (2014) found that populations of wild, forage, and ornamental North American and European reed canarygrass had high levels of genetic diversity within, rather than among, populations; this was confirmed in additional studies (Anderson et al., 2018; Kávová et al., 2017; Nelson and Anderson, 2015). At least one European forage cultivar [e.g., Chrastava (Cagaš, 2008)] was genetically similar to wild European populations (Anderson et al., 2016). All extant and historic herbaria specimens of reed canarygrass in Minnesota were found to be native and genetically distinct from European samples, based on SNP and ITS data (Graper et al., 2021; Noyszewski et al., 2018, 2019, 2020, 2021).

INVASIVE SPREAD. The theorized role of forage and ornamental cultivars in increasing the spread of invasive reed canarygrass across North America (Merigliano and Lesica, 1998) is unsubstantiated (Casler et al., 2009; Jakubowski et al., 2011). Cross-pollination among native North American and European types would be possible since grasses are wind pollinated and reed canarygrass is selfincompatible (Casler and Hovin, 1984; Jakubowski et al., 2013). This would alter the North American gene pool (Vila et al., 2000). An increase in reed canarygrass' North American range is not a result of hybridization among European, forage, and North American individuals (Jakubowski et al., 2011), particularly from SNP data (Noyszewski et al., 2018, 2019, 2020, 2021), despite unsubstantiated theories to the contrary (Lavergne and Molofsky, 2007).

Despite these evidential data on the native status of at least some populations throughout North America, many invasion biology researchers continued to posit that reed canarygrass is exotic and native only to Eurasia as well as being introduced to North America. These encompass a range of hypotheses from the importation of invasive forage types from Eurasia (Dore and McNeill, 1980; Lavergne and Molofsky, 2004), cross hybridization between Eurasian and North American populations (Lavergne and Molofsky, 2007), as well as the release of individuals with hybrid vigor (Merigliano and Lesica, 1998). However, if ecologists were familiarized with all scientific literature, it would have become clear that early 1940 s reed canarygrass breeding in Canada and the United States had used native North American land races (Carlson et al., 1996). 'Auburn', 'Superior', and 'Ioreed' forage types were selected directly from land races (Casler, 2010) and large cultivated populations were derived from native stands in the Rocky Mountain states and southern Canadian provinces (Schoth, 1938). These facts, along with the substantive use of reed canarygrass by Native Americans through the centuries (Densmore, 1974; Kindscher and Noguera, 2002; Turner et al., 1980), provide additional assurances that many populations of reed canarygrass in North America were and are native.

Additional propagule pressure may have arisen from the primary reed canarygrass producers of commercial forage seed production in Saskatchewan, Canada (Statistique Canada,
2001), and Roseau, MN (Seed Today, 2012), as well as ornamental clones worldwide. Its displacement of other native species is undisputed (Miller and Zedler, 2003; Zedler and Kercher, 2004). Significant costs have been realized in its control and corresponding restoration efforts (Reinhardt Adams and Galatowitsch, 2005).

Ornamental 'Picta' ribbon grass also naturally occurs as wild populations in North America (Barkworth et al., 2007). Lavoie et al. (2005) proposed an invasion window during 1923-43 for reed canarygrass in Canada, which was the result of native 'Picta' being sold in Montréal nurseries in 1834 onwards (Guilbaut, 1834). 'Picta' is, thus, one example of the native North American yet invasive species' spread. This first invasion window cannot be attributed to early Canadian forage cultivars, since they were not licensed until years later (in 1959) and distribution occurred even later from 1965 onwards (Bittman et al., 1980; Goplen et al., 1964). A second Canadian invasion window was during 1963-78, this time with pure, native reed canarygrass, most likely due to high nutrient runoff from agricultural fields, increased production of low alkaloid cultivars in commercial fields, human disturbance such as the building of highway corridors, and water level changes (Lavoie et al., 2005).

An additional native, invasive spread hypothesis includes the midwestern United States dispersal of reed canarygrass (Anderson, 2019). Our recent discovery of the distribution of hay across the midwestern United States from the unplowed field in Roseau, MN, during the Dust Bowl era warrants further investigations. In herbaria across North America, reed canarygrass specimens predating the Dust Bowl (1930-40) are numerous, as they were frequently collected by explorerbotanists (Jakubowski et al., 2011, 2013). All Minnesota and Wisconsin herbaria specimens predating the 1930s dustbowl are native (Jakubowski et al., 2011, 2013; Noyszewski et al., 2019). Thus, we propose that an additional invasion window occurred in the United States from the 1930s to the present day, which overlaps with the first invasion window in Canada. However, the question remains what the impact of the spread of native, European, or their hybrids means for 
agencies, regulators, tribal land managers, public land managers, private land managers, and NGOs (Table 1). Decision making and new risk assessment models or invasive species predictive schemes (Whitney and Gabler, 2008) would be required to reevaluate the status of native, invasive reed canarygrass for all organizations (Table 1).

\section{Monitoring and regulatory U.S. federal agencies}

U.S. federal agencies and programs that work on reed canarygrass monitoring include the U.S. Department of Agriculture (USDA); the Animal and Plant Health Inspection Service (APHIS); the Federal Noxious Weed List; Plant Protection and Quarantine (PPQ); the interagency Aquatic Nuisance Species Taskforce; the U.S. Army Corps of Engineers Noxious and Nuisance Plant Management Information System; the U.S. Bureau of Land Management; the U.S. Department of Defense Environmental Network and Information Exchange (DENIX); the U.S. Federal Highway Administration; and the U.S. Fish and Wildlife Service (USFWS) Invasive Species Program (Table 1). These agencies produce listings, based on their jurisdictions along with additional input from the National Invasive Species Information Center, the National Agricultural Pest Information Center, and the U.S. National Plant Board (Table 1). Monitoring agencies in the separate 50 U.S. States, the 10 Canadian Provinces and its three territories as well as local or municipal government listings in both countries were not included due to their inherent complexity.

The included U.S. federal agencies show that, for "native, noninvasive" species, the reference point is for identifying and preventing entry or exit of endangered or threatened species, based on the Convention on International Trade in Endangered Species (1975) (Table 1). Although reed canarygrass is neither endangered or threatened, apparently no listings or regulations for any "native, noninvasive" species exist (Table 1).

For the categories of "exotic, noninvasive" and "exotic, invasive," the importation or exportation of the species may be regulated, particularly if they affect commercial agriculture and interstate commerce (Table 1).
Such species would be added to existing noxious weed lists and import/ export lists of allowable species by the following agencies. USDA-APHIS (2010) maintains the Federal Noxious Weed List, which controls import/ export through USDA-APHIS-PPQ. The U.S. Department of Defense (2019) maintains DENIX. The U.S. Army Corps of Engineers previously published an Army Corps Noxious and Nuisance Plant Management Information System (website no longer available) but now has a nationwide Invasive Species Policy, which applies to all Civil Works projects (U.S. Department of the Navy and U.S. Army Corps of Engineers, 2009) (Table 1). The National Invasive Species Act (U.S. Congress, 1996) cojoins with the U.S. Army Corps of Engineers to "either prevent or reduce establishment of invasive and nonnative species." The U.S. Bureau of Land Management (2006) published "The Weed Hall of Shame" and also provides information on weeds and invasives (U.S. Bureau of Land Management, n.d.) (Table 1). The USFWS (2015) provides an Invasive Species Program (2015). The U.S. Federal Highway Administration defines invasive species as "Non-native [sic.] flora and fauna that can cause significant changes to ecosystems, upset the ecological balance, and cause economic harm to the agricultural and recreational sectors" (U.S. Department of Transportation, Federal Highway Commission, n.d.). Additional advisory taskforces or boards for U.S. federal agencies include: the Aquatic Nuisance Species Taskforce (2011), the USDA National Invasive Species Information Center (n.d.), National Agricultural Pest Information Center (2004), and the U.S. National Plant Board (2014).

Reed canarygrass is neither listed on any of the U.S. federal agency listings nor by any advisory taskforce or board listings (Table 1). Thus, the change in designation for most, if not all, populations of reed canarygrass in Minnesota (Noyszewski et al., 2020, 2021 ) from an "exotic, invasive" to a "native, invasive" should not presently be affected by U.S. federal agencies and regulations.

\section{Tribal land managers}

The Great Lakes Indian Fish and Wildlife Commission-Exotic Plants
(GLIFWC; Falk et al., 2015) provides for invasive species reporting, species account listings, risks assessment models, and species distribution models for tribal land managers in states and provinces surrounding the Great Lakes, which includes portions of the State of Minnesota (Table 1). The 11 Minnesota Tribal Nations, namely the Bois Forte Band of Chippewa (2021), Fond Du Lac Band of Lake Superior Chippewa (2021), Grand Portage Band of Lake Superior Chippewa (2021), Leech Lake Band of Ojibwe (2021), Lower Sioux Indian Community (2021), Mille Lacs Band of Ojibwe (2021), Prairie Island Indian Community (2021), Red Lake Nation (2019), Shakopee Mdewakanton Sioux (Dakota) Community (2021), Upper Sioux Community (2021), and the White Earth Nation (2021) may also have specific recommendations and reporting for invasive species control.

Reed canarygrass is listed and searchable as an "exotic, invasive" species in GLIFWC (2019), although no invasive species model has been created (Table 1). Initial discussions with some of the Minnesota Tribal Nations revealed no current knowledge of using reed canarygrass in weavings nor of its native status (E. Ito, D. Dalbotten, and H. Pellerin, personal communication). Deliberations within and among the Minnesota Tribal Nations as well as with GLIFWC regarding the "native, invasive" status of reed canarygrass may change the current classification of this species. Until that has been accomplished, actions by tribal land managers are uncertain. Likewise, future efforts for potential control of reed canarygrass would seem unlikely because this is a native species with cultural heritage ties both in Minnesota and elsewhere throughout North America.

Identification of "exotic, invasive" Eurasia species growing within "native, invasive" stands of reed canarygrass in Tribal Nations would require extensive and costly SNP testing for nuclear DNA (Noyszewski et al., 2019, 2020, 2021) until specific genetic sequences are identified to distinguish between Eurasian and North American species. While the chloroplast genome has been sequenced in reed canarygrass (Xiong et al., 2020), it has not yet been completed for the nuclear genome where the SNP markers are located. On the 
other hand, ITS regions may hold possibilities for earlier detection of native vs. exotic reed canarygrass accessions, provided our initial ITS findings (that separated most native, North American types in Minnesota from elsewhere in the U.S. and Eurasia) are accurate (Noyszewski et al., 2021).

\section{Public land managers (State of Minnesota)}

For "native, noninvasive" species, the State of Minnesota Department of Natural Resources (MNDNR), provides vascular plant checklists in two resources: The Native Plant Encyclopedia (MNDNR, 202la) and MnTaxa: The State of Minnesota Vascular Plant Checklist (MNDNR, 202 lb). A definition of interest is provided: "native" is exclusive of "invasive." This would require modification for reed canarygrass identified as "native, invasive" (Noyszewski et al., 2019, $2020,2021)$ as well as for other species in this category, such as poison ivy (Toxicodendron radicans Kuntze ssp. negundo Gillis). The Minnesota Invasive Species Taskforce provides categorical definitions in Minnesota Noxious Weed Risk Assessments [Minnesota Invasives Species Advisory Council (MISAC), 2020] by answering the question: "Is the plant species or genotype nonnative?" with either "disputed, yes, and no."

Reed canarygrass is not listed in The Native Plant Encyclopedia but is found in MnTaxa with a listing as invasive. As such, it would require reclassification as "native, invasive" reed canarygrass. In contrast, the Minnesota Department of Transportation (MNDOT, 2020) has a Minnesota Noxious Weeds list, which lists a "Specially Regulated" category for "native, invasive" species (e.g., poison ivy; Table 1). However, reed canarygrass is not included in this category and should be.

For "exotic, noninvasives," both the MNDNR and MNDOT do not recognize this category, and thus, reed canarygrass is not listed. The "exotic, invasive" category in the MNDNR provides an Invasive, Nonnative Plant list (MNDNR, 2021c), as well as an Invasive Terrestrial Plant list (MNDNR, 2021d); reed canarygrass is in the latter listing because it "outcompetes most native species in natural wetlands" (Table 1). MNTaxa also lists reed canarygrass as "Invasive" (MNDNR, 2021e). MNDOT has four classifications for "exotic, invasive" species: Prohibited, Eradicate; Prohibited, Control; Restricted Noxious Weeds; and Specially Regulated (MNDOT, 2020) (Table 1). Reed canarygrass, however, is not listed herein. In coordination with MISAC (2020), Minnesota Department of Agriculture's (MNDA) Invasive Species Programs provide four classifications for "exotic, invasive" species: Plant Protection, Pest Detection and Management Unit, Weed Team, Noxious Weed Law, Early Detection (Table 1). This program, however, lacks any species listings; thus, reed canarygrass is also not included herein.

Public land managers within the State of Minnesota are thus confronted with myriad issues, depending on the state agency in which they operate as well as lack of listings and/or conflicting categorizations across agencies. These all would require modification to accommodate the new findings that reed canarygrass populations in Minnesota are predominantly, if not exclusively, "native, invasive" instead of being classified as "exotic, invasive." Such changes would require legislative action by the Minnesota Legislature to affect changes throughout the Minnesota Terrestrial Invasive Plant Resources listings (Minnesota Board of Soil and Water Resources, 2011) and the Minnesota State Management Plan for Invasive Species (MNDNR, 2009). Current discussions have included a range of responses from land managers tasked with the control and eradication of reed canarygrass from public lands (N.O. Anderson, unpublished data), based on control methods recommended by USDA Natural Resources Conservation Service (2002). Some welcome potential changes to accommodate the new listing of reed canarygrass as a "native, invasive" although whether this change would alter current management plans is unclear. These could range from no change in control approaches to selective control of particularly aggressive populations that threatens water resources or rare/ endangered native species.

The lack of regulation in the State of Minnesota for reed canarygrass (MNDNR, 202lf) and its classification as a "nuisance species," differs from at least three other U.S. states.
In the State of Connecticut, reed canarygrass is listed as "invasive" but not regulated (University of Connecticut, Connecticut Invasive Plant Working Group, 2018) whereas in the adjacent Commonwealth of Massachusetts, as an invasive species it is listed as "prohibited" (Massachusetts Natural Resources Council, 2021). Only Washington State lists it as a "Class C noxious weed" (Washington State Noxious Weed Control Board, 1995). If future research proves that additional populations of reed canarygrass in these and other U.S. states and/or Canadian provinces are also native to North America, the reformulation of approaches in the State of Minnesota may have applicable value to these states.

\section{Private land managers (State of Minnesota)}

The Nature Conservancy (2021) is a large primary private land holder in the State of Minnesota that protects native plant communities and controls invasive species on its lands of 60,845 acres (S. Edmunds, personal communication). Reed canarygrass is not listed in any category, particularly as an "exotic, invasive" species (Table 1). Additional smaller private landowners, such as residential properties, would be mandated to follow state regulations for invasive species control should they be legislated. Thus, any private land manager is at liberty to control or not control reed canarygrass on their lands at their discretion. It remains to be seen whether the reclassification of reed canarygrass as a "native, invasive" species would change landowners' perspectives on its control.

\section{NGOs (State of Minnesota)}

A wide variety of NGOs operate in various capacities with differing services in the State of Minnesota (Table 1). For "native noninvasive" species, the Minnesota Native Plant Society (MNPS, 2021) is dedicated to the preservation of native plant species within the state. The MNPS Conservation Committee informs the membership on "issues relating to conservation, including, but not limited to, promotion of the use of native plant species, preservation of native plant species and communities, and conservation of rare and endangered 
species." Thus, invasive species control would be of paramount interest in this organization, which may result in lobbying efforts and other supportive roles to public and private as well as tribal land managers. As part of the MNDNR, Restore Your Shore is an advisory group that published an online searchable database: Native Plant Encyclopedia (MNDNR, 2019). The University of Minnesota Andersen Horticulture Library maintains an online searchable database, Plant Information Online (University of Minnesota Libraries, 2021), listing "native" and cultivated ("native" as well as "exotic") horticultural crop species and cultivars currently on the North American market (Table 1).

Within the "native, invasive" species as well as "exotic, invasive" categories, NGOs such as EDDMapS (University of Georgia, 2021) can be used to search and/or add invasive species (Table 1). Reed canarygrass is listed in Minnesota with 20,723 positive reports in Minnesota as of 1 Jan. 2021 (University of Georgia, 2021). An added caveat in the species description notes that "Nativity of this plant is debated; it is native to Europe and possibly parts of Asia, but it may also be native to NW U.S." For the category of "exotic, noninvasive" species, one can readily search both EDDMapS and the Plant Information Online database (Table 1). Thus, in EDDMapS, reed canarygrass is correctly listed as both a "native, invasive" for North American types as well as an "exotic, invasive" for Eurasian individuals. The impact of NGOs for land managers responsible for reed canarygrass control and mitigation would primarily be restricted to being advisory sources.

\section{Conclusions}

While invasion biology as a science has many rigorous foundations and tenets, care must be taken to avoid and minimize motivational subjectivity in terminology for scientific discovery (Colautti and Richardson, 2009). Testing with molecular tools, such as ITS and SNP markers, should be used to determine the continent of origin (Graper et al., 2021; Noyszewski et al., 2021). Greater attention is necessary to ensure that assumptions are rigorously vetted in reference to equilibrium of species in their native range, recurring uncertainty for all constraints in risk assessment, and continued evolution of all species regardless of their native origin or tendency to spread in either native or nonnative ranges (Broennimann and Guisan, 2008). Thus, a thorough and deliberative reevaluation and reassessment of reed canarygrass by all interest groups as a native, invasive species in Minnesota and elsewhere in North America is warranted before any party can propose sound solutions for its preservation and/or control.

\section{Literature cited}

Akiyama, Y., K. Kimura, A. Kubota, M. Fujimori, H. Yamada-Akiyama, Y. Takahara, and Y. Ueyama. 2015. Comparison of genome size in reed canarygrass (Phalaris arundinacea L.) exotic and putative native Japanese individuals by flow cytometry. Jpn. Agr. Res. Q. 49:345-350, doi: 10.6090/jarq.49.345.

Alway, F.J. 1931. Early trials and use of reed canary grass as a forage plant. J. Amer. Soc. Agron. 23:64-66.

Ambros, Z. and J. Štykar. 1999. Geobiocenologie I. Mendelova zemědělská a lesnická univerzita v Brně, Brno, Czech Republic.

Anderson, D.E. 1961. Taxonomy and distribution of the genus Phalaris. Iowa State Coll. J. Sci. 36:1-96.

Anderson, N.O. 2019. Throwing out the bathwater but keeping the baby: Lessons learned from purple loosestrife and reed canarygrass. HortTechnology 29:539-548, doi: 10.21273/HORTTECH04307-19.

Anderson, N.O. and S.M. Galatowitsch (eds.). 2006a. Plant breeding and crop domestication as sources of new invasive species. Euphytica 148:1-216.

Anderson, N.O., N. Gomez, and S.M. Galatowitsch. 2006b. A non-invasive crop ideotype to reduce invasive potential. Euphytica 148:185-202.

Anderson, N.O., S.M. Galatowitsch, and N. Gomez. 2006c. Selection strategies to reduce invasive potential in introduced plants. Euphytica 148:203-216.

Anderson, N.O., T. Kávová, D. Bastlová, V. Čurn, B. Kubátová, K.R. Edwards, V. Januš, and J. Květ. 2016. Phenotypic and genotypic variation in Czech forage, ornamental and wild populations of reed canarygrass. Crop Sci. 56:2421-2435, doi: 10.2135/cropsci2015.11.0705.

Anderson, N.O., L. Jociene, E. Krokaite, T. Rekašius, A. Paulauskas, and E. Kupčinskienè. 2018. Genetic diversity of Phalaris arundinacea populations in relation to river regulation in the Merkys Basin,
Lithuania. River Res. Appl. 34:300-309, doi: $10.1002 /$ rra.3259.

Anderson, N.O., A. Noyszewski, A.G. Smith, A. Kilian, E. Ito, D. Dalbotten, A. Timm, and H. Pellerin. 2020a. Management and control issues for native, invasive species: Philosophical, managerial and legislative issues. HortScience 55(9S):S191. (Abstr.).

Anderson, N.O., A. Noyszewski, A.G. Smith, D. Dalbotten, E. Ito, A. Timm, and H. Pellerin. 2020b. Reed canarygrass: Implications for control of an invasive species when it is native. 1 Aug. 2020. <https://www.umisc.net/uploads/1/0/ 7/5/10750703/umisc_2020_complete_ agenda_-_9-24-20.pdf>. (Abstr.).

Aquatic Nuisance Species Taskforce. 2011. Aquatic nuisance species (ANS). 12 Mar. 2021. <https://www.anstaskforce. gov/default.php $>$.

Baker, H.G. and G.L. Stebbins (eds.). 1965. The genetics of colonizing species: Proceedings of the International Union of Biological Sciences. Academic Press, New York, NY.

Barkworth, M.E., K.M. Capels, S. Long, L.K. Anderton, and M.B. Piep (eds.). 2007. Flora of North America north of Mexico, Vol. 24: Magnoliophyta: Commelinidae (in part): Poaceae, part 1. Oxford Univ. Press, New York, NY.

Bazzaz, F.A. 1986. Life history of colonizing plants: Some demographic, genetic, and physiological features, p. 96-110. in H.A. Mooney and J. A. Drake (eds.). Ecology of biological invasions of North America and Hawaii. Springer-Verlag, New York, NY.

Bittman, S., J. Waddington, B.E. Coulman, and S.G. Bonin. 1980. Reed canarygrass: A production guide. Agr. Canada Pub. 805 .

Bois Forte Band of Chippewa. 2021. Welcome to the Bois Forte Band of Chippewa. 12 Mar. 2021. <https://boisforte. $\mathrm{com} />$.

Broennimann, O. and A. Guisan. 2008. Predicting current and future biological invasions: Both native and invaded ranges matter. Biol. Lett. 4:585-589, doi: 10.1098/rsbl.2008.0254.

Cagaš, B. 2008. Reed canary grass 'Chrastava'. Czech J. Genet. Plant Breed. $44: 41-42$

Carlson, I.T., R.N. Oram, and J. Surprenant. 1996. Reed canarygrass and other Phalaris species, p. 569-604. In: L.E. Moser, D.R. Buxton, and M.D. Casler (eds.). Coolseason forage grasses. Agron. Monogr. No. 34. Amer. Soc. Agron., Madison, WI. 
Carlton, J.T. 1996. Biological invasions and cryptogenic species. Ecology 77: 1653-1654.

Casler, M.D. 2010. Genetics, breeding, and ecology of reed canarygrass. Intl. J. Plant Breed. 4:30-36.

Casler, M.D. and A.W. Hovin. 1984. Genotype $\mathrm{x}$ environment interaction for reed canarygrass forage yield (Phalaris arundinacea, stability analysis). Crop Sci. 24:633-636.

Casler, M.D. and D.J. Undersander. 2006. Selection for establishment capacity in reed canary grass. Crop Sci. 46:1277-1285.

Casler, M.D., J.H. Cherney, and E.C. Brummer. 2009. Biomass yield of naturalized populations and cultivars of reed canarygrass. BioEnergy Res. 2:165-173.

Chekol, T., L.R. Vough, and R.L. Chaney. 2002. Plant-soil-contaminant specificity affects phytoremediation of organic contaminants. Intl. J. Phytoremediation 4:17-26.

Chew, M.K. and A. Hamilton. A. 2011. The rise and fall of biotic nativeness: A historical perspective, p. 35-48. In: D.M. Richardson (ed.). Fifty years of invasion ecology: The legacy of Charles Elton. Wiley, New York, NY.

Č́žková, H., J. Rychterová, L. Hamadejová, K. Suchý, M. Filipová, J. Květ, and N.O. Anderson. 2015. Biomass production in permanent wet grasslands dominated with Phalaris arundinacea: Case study of the Třebon̆ basin biosphere reserve, Czech Republic, p. 1-16. In: V. Vymazal (ed.). The role of natural and constructed wetlands in nutrient cycling and retention on the landscape. Springer, Bern, Switzerland, doi: 10.1007/ 978-3-319-08177-9_1.

Coates, P. 2006. American perceptions of immigrant and invasive species. Univ. California Press, Berkeley, CA.

Colautti, R.I. and M. Richardson. 2009. Subjectivity and flexibility in invasion terminology: Too much of a good thing? Biol. Inv. 11:1225-1229, doi: 10.1007/ s10530-008-9333-z.

Convention on International Trade in Endangered Species. 1975. The CITES species. 12 Jan. 2019. < https://cites.org/eng > .

Crawley, M.J., P.H. Harvey, and A. Purvis. 1996. Comparative ecology of the native and alien floras of the British Isles. Phil. Trans. Roy. Soc. London Ser. B 351:1251-1259.

Čuda, J., H. Skálová, Z. Janovský, and P. Pyšek. 2014. Habitat requirements, shortterm population dynamics and coexistence of native and invasive Impatiens species: a field study. Biol. Invasions 16:177-190, doi: $10.1007 /$ s10530-013-0512-1.

Daehler, C. 1998. The taxonomic distribution of invasive angiosperm plants: Ecological insights and comparison to agricultural weeds. Biol. Conserv. 84:167-180.

Daehler, C.C. 2001. Two ways to be an invader, but one is more suitable for ecology. ESA Bull. 82:101-102.

Davis, M.A. 2006. Invasion biology 1958-2005: The pursuit of science and conservation, p. 35-64. In: M.W. Cadotte, S.M. McMahon, and T. Fukami (eds.). Conceptual ecology and invasion biology. Springer, Dordrecht, The Netherlands.

Davis, M.A. and K. Thompson. 2001. Invasion terminology: Should ecologists define their terms differently than others? No, not if we want to be of any help. ESA Bull. 82:206.

Davis, M.A., J.P. Grime, and K. Thompson. 2000. Fluctuating resources in plant communities: A general theory of invisibility. J. Ecol. 88:528-534, doi: 10.1046/j.13652745.2000.00473.x.

Densmore, F. 1974. How Indians use wild plants for food, medicine, and crafts. Courier Dover Pub., Mineola, NY.

Dore, W.G. and J. McNeill. 1980. Grasses of Ontario. Res. Br., Agric. Canada, Monogr. No. 26. Ottawa, ON, Canada.

Elton, C.S. 1958. The ecology of invasions by animals and plants. Methuen, London, UK.

European Union. 2010. Developing an EU framework for invasive alien species discussion paper (Final). 12 Jan. 2010. <https:// ec.europa.eu/environment/nature / invasivealien/docs/ias_discussion_paper. pdf $>$.

Falk, M., D.J.O. Unglaube, and R. Parisien. 2015. Invasive species program. 12 Mar. 2021. <http://www.glifwc.org/>.

Figiel, C.R., B. Collins, and G. Wein. 1995. Variation in survival and biomass of two wetland grasses at different nutrient and water levels over a six week period. Bull. Torrey Bot. Club 122:24-29.

Fond du Lac Band of Lake Superior Chippewa. 2021. The Fond du Lac Band of Lake Superior Chippewa. 12 Mar. 2021. <http://www.fdlrez.com/>.

Fox, M.D. 1990. Mediterranean weeds: Exchanges of invasive plants between the five Mediterranean regions of the world, p. 179-200. In: F. Di Castri, A.J. Hansen, and M. Debussche (eds.). Biological invasions in Europe and the Mediterranean basin. Kluwer Academic, Dordrecht, The Netherlands.
Frank, D.M. 2019. Disagreement or denialism? "Invasive species denialism" and ethical disagreement in science. Synthese, doi: 10.1007/s11229-019-02259-w.

Galatowitsch, S.M., N.O. Anderson, and P.D. Ascher. 1999. Invasiveness in wetland plants in temperate North America. Wetlands 19:733-755. <http://www. sgnis.org $>$.

Gifford, A.L.S., J.B. Ferdy, and J. Molofsky. 2002. Genetic composition and morphological variation among populations of the invasive grass, Phalaris arundinacea. Can. J. Bot. 80:779-785.

Goodenough, A.E. 2010. Are the ecological impacts of alien species misrepresented? A review of the "native good, alien bad" philosophy. Comm. Ecol. 11:13-21, doi: 10.1556/ComEc.11.2010.1.3.

Goplen, B.P., S.G. Bonin, W.E.P. Davis and R.M. MacVicar. 1964. L'alpiste roseau. Ministère de l'Agriculture, Pub. 805.

Grand Portage Band of Lake Superior Chippewa. 2021. Gichi-Onigaming/Grand Portage Band of Lake Superior Chippewa. 12 Mar. 2021. <https://mn.gov/indian affairs/grandportage-iac.html $>$.

Graper, A.L., A.K. Noyszewski, N.O. Anderson, and A.G. Smith. 2021. Variability in ITS1 and ITS2 sequences of historic (herbaria) and extant (fresh) Phalaris species. BMC Plant Biol. (In press).

Great Lakes Indian Fish \& Wildlife Commission. 2019. Stop the spread of aquatic invasives! 20 June 2020. <https://data.glifwc. org/ais/Phalaris_arundinacea/id.html $>$.

Green, R.E. 1997. The influence of numbers released on the outcome of attempts to introduce exotic bird species to New Zealand. J. An. Ecol. 66:25-35.

Guilbaut, S. 1834. Catalogue of fruit and ornamental trees, flowering shrubs and plants, green-house shrubs and plants, bulbous flower roots, American and Indigenous trees and plants, flower and garden seeds, cultivated and for sale at Guilbault's Botanic Garden, CoteauBaron, St. Lawrence Street, Montréal. Ludger Duvernay, Montréal, QC, Canada.

Gyulai, G., Z. Mester, J. Kiss, L. Szeman, A. Idnurm, and L. Heszky. 2003. Somaclonal breeding of reed canary grass ( $\mathrm{Pha}$ laris arundinacea L.). Grass Forage Sci. 58:210-214.

Harris, A. 1835. Ribbon grass. New England Farmer 14:125.

Holm, L.G., J.K. Pancho, J.P. Herberger, and P.L. Plunkett. 1991. A geographical atlas of world weeds. Krieger, Malabar, FL. 
Houlahan, J.E. and C.S. Findlay. 2004. Effect of invasive plant species on temperate wetland plant diversity. Conserv. Biol. 18:1132-1138, doi: 10.1111/j.15231739.2004.00391.x.

Hroudová, Z., R. Hrivnák R, and H. Chytrŷ. 2009. Classification of inland Bolboschoenus-dominated vegetation in Central Europe. Phytocoenologia 39:205-215.

Hussey, B.M.J., D. Anderson, and S. Loney. 1992. A checklist of plants found growing in a native or naturalized state on Culeenup Island, Yunderup, Western Australia. W. Austr. Nat. 19:35-43.

Iannone, B.V., III, S. Carnevale, M.B. Main, J.E. Hill, J.B. McConnell, S.A. Johnson, S.F. Enloe, M. Andreu, E.C. Bell, J.P. Cuda, and S.M. Baker. 2020. Invasive Species Terminology: Standardizing for Stakeholder Education. J. Ext. 58:v58-3a3. I May 2021. <https:// archives.joe.org/joe/2020june/a3.php>.

Illinois Industrial University. 1872. Fourth annual report of the Board of Trustees of the Illinois Industrial University for the year 1870-1 embracing the academic year and subsequent vacation with lectures, etc. Illinois J. Print. Off., Springfield, IL.

International Union for the Conservation of Nature. 2021. Invasive species. 13 Mar. 2020. <https://www.iucn.org/theme/ species/our-work/invasive-species $>$.

Jakubowski, A.R., M.D. Casler, M. Denton, D. Costich, E. Buckler, M. Phillips, R. Jackson, and A. Krohn. 2010. DNA markers and sequences reveal geographic races of reed canarygrass (Phalaris arundinacea). Proc. 6th Int. Symp. Mol. Breed. Forage Turf, 15-19 Mar. 2010, Buenos Aires, Argentina. Abstract P-44. (Abstr.).

Jakubowski, A.R., M.D. Casler, and R.D. Jackson. 2011. Has selection for improved agronomic traits made reed canarygrass invasive? PLoS One 6:e25757, doi: 10.1371/journal.pone.0025757.

Jakubowski, A.R., M.D. Casler, and R.D. Jackson. 2013. Genetic evidence suggests a widespread distribution of native North American populations of reed canarygrass. Biol. Inv. 15:261-268.

Kávová, T., B. Kubátová, V. Čurn, and N.O. Anderson. 2017. Genetic variability of US and Czech Phalaris arundinacea L. wild and cultivated populations. InTech Forage, New Perspectives in Forage Crops, doi: 10.5772/intechopen.69669.

Kercher, S.M. and J.B. Zedler. 2004. Multiple disturbances accelerate invasion of reed canary grass (Phalaris arundinacea L.) in a mesocosm study. Oecologia 138:455-464.
Kettenring, K.M., D.R. Menuz, and K.E. Mock. 2019. The nativity and distribution of the cryptic invader Phalaris arundinacea (reed canarygrass) in riparian areas of the Columbia and Missouri river basins. Wetlands 39:55-66, doi: 10.1007/s13 157-018-1074-x.

Kindscher, K. and E. Noguera. 2002. Cultural use of plants from the Baker Wetlands. Prepared for the Technical outreach Services for Native American Communities (TOSNAC) at Haskell Indian Nations University. Kansas Biol. Survey, Univ. of Kansas, Manhattan, KS.

Lavergne, S. and J. Molofsky. 2004. Reed canary grass (Phalaris arundinacea) as a biological model in the study of plant invasions. Crit. Rev. Plant Sci. 23:415-429, doi: 10.1080/07352680490505934.

Lavergne, S. and J. Molofsky. 2007. Increased genetic variation and evolutionary potential drive the success of an invasive grass. Proc. Natl. Acad. Sci. USA 104:3883-3888.

Lavoie, C., J. Martin, F. Delisle, and G. Létourneau. 2003. Exotic plant species of the St Lawrence River wetlands: A spatial and historical analysis. J. Biogeogr. 30: 537-549.

Lavoie, C., C. Dufresne, and F. Delisle. 2005. The spread of reed canary grass (Phalaris arundinacea) in Québec: A spatio-temporal perspective. Ecoscience 12: 355-375.

Leech Lake Band of Ojibwe. 2021. Welcome to the Leech Lake Band of Ojibwe. 12 Mar. 2021. <http://www.llojibwe.com/>.

Long, G. 2011. Disagreement and responses to climate change. Environ. Values 20:503-525.

Lonsdale, W.M. 1994. Inviting trouble: Introduced pasture species in northern Australia. Aust. J. Ecol. 19:345-354.

Lower Sioux Indian Community. 2021. The Lower Sioux Indian Community welcomes you. 12 Mar. 2021. <https:// lowersioux.com $/>$.

Mack, R.M., D.W. Simberloff, M. Lonsdale, H. Evans, M. Clout, and F.A. Bazzaz. 2000. Biotic invasions: Causes, epidemiology, global consequences, and control. Ecol. Appl. 10:689-710, doi: 10.1890/1051-0761(2000)010[0689:BI CEGC]2.0.CO;2.

Marten, G.C. and M.E. Heath. 1985. Reed canarygrass, p. 207-216. In: M.E. Heath, R.F. Barnes, and D.S. Metcalfe (eds.). Forages: The science of grassland agriculture. Iowa State Univ. Press, Ames, IA.

Massachusetts Natural Resources Council. 2021. Massachusetts invasive plant advisory group. 12 Mar. 2021. <https:// www.massnrc.org/mipag/invasive.htm $>$.

Merigliano, M.F. and P. Lesica. 1998. The native status of reed canarygrass ( $\mathrm{Pha}$ laris arundinacea L.) in the inland northwest, USA. Nat. Areas J. 18:223-230.

Meyer, J.Y. and J. Florence. 1996. Tahiti's native flora endangered by the invasion of Miconia calvescens DC. (Melastomaceae). J. Biogeogr. 23:775-781.

Mille Lacs Band of Ojibwe. 2021. Boozhoo, and welcome to website of the Mille Lacs Band of Ojibwe. 12 Mar. 2021. <https://millelacsband.com/about/millelacs-band-of-ojibwe $>$.

Miller, R.C. and J.B. Zedler. 2003. Responses of native and invasive wetland plants to hydroperiod and water depth. Plant Ecol. 167:57-69.

Minnesota Board of Soil and Water Resources. 2011. Minnesota terrestrial invasive plant resources. 20 June 2020. <https:// bwsr.state.mn.us/sites/default/files/201812/Minnesota_Invasive_Plant_Species_ Resources.pdf $>$.

Minnesota Department of Natural Resources. 2009. A Minnesota state management plan for invasive species. 20 June 2020. $<$ http://files.dnr.state.mn.us/natural_ resources/invasives/state_invasive_species_ plan.pdf $>$.

Minnesota Department of Natural Resources. 2019. Restore your shore native plant encyclopedia. 20 June 2020. <https:// webapps 15.dnr.state.mn.us/restore_ your_shore $>$.

Minnesota Department of Natural Resources. 2021a. Native plant encyclopedia. 12 Mar. 2021. <https://www.dnr.state. mn.us/rys/pg/encyclopedia.html $>$.

Minnesota Department of Natural Resources. 2021b. MNTaxa: The State of Minnesota vascular plant checklist. 12 Mar. 2021. <https://www.dnr.state.mn. us/eco/mcbs/plant_lists.html $>$.

Minnesota Department of Natural Resources. 2021c. Invasive non-native plants. 12 Mar. 2021. <https://www.dnr.state. mn.us/rys/pg/invasive.html $>$.

Minnesota Department of Natural Resources. 2021d. Invasive terrestrial plants. 12 Mar. 2021. <https://www.dnr.state.mn. us/invasives/terrestrialplants/index.html>.

Minnesota Department of Natural Resources. 2021e. Species lists and county maps. 12 Mar. 2021. <https://webapps15. dnr.state.mn.us/mntaxa/reports/index $>$.

Minnesota Department of Natural Resources. 2021f. Reed canary grass (Phalaris arundinacea). 12 Mar. 20221. <https:// 
www.dnr.state.mn.us/invasives/terrestrial plants/grasses/reedcanarygrass.html>.

Minnesota Department of Transportation. 2020. Minnesota noxious weeds: Includes native and nonnative look-alike species for comparison. 30 June 2020. <https://www. dot.state.mn.us/roadsides/vegetation/ pdf/noxiousweeds.pdf $>$.

Minnesota Invasive Species Advisory Council. 2020. Minnesota noxious weed risk assessments. 12 June 2020. <https:// www.mninvasives.org/risk-assessments $>$.

Minnesota Native Plant Society. 2021. Minnesota Native Plant Society: Dedicated to the conservation and appreciation of Minnesota's native plants and plant communities. 12 Mar. 2021. <http:// mnnps.org/>

National Agricultural Pest Information System. 2004. NAPIS is the database for Cooperative Agricultural Pest Survey and related pest detection surveys. 12 Mar. 2021. $<$ https://napis.ceris.purdue.edu/home $>$.

Nelson, M.F. and N.O. Anderson. 2015. Variation among individuals and source habitats in growth and fecundity of the wetland invasive plant Phalaris arundinacea L. Wetlands 35:1175-1184, doi: 10.1007/ s13157-015-0704-9.

Nelson, N.F., N.O. Anderson, M.D. Casler, and A.R. Jakubowski. 2014. Population genetic structure of North American and European Phalaris arundinacea L. as inferred from inter-simple sequence repeat markers. Biol. Inv. 16:353-363, doi: 10.1007/s10 530-013-0525-9.

New England Farmer. 1834. Ribbon grass. New England Farmer 13:41, 129.

Newman, P.C. 1985. Company of adventurers. Penguin Books, Markham, ON, Canada.

Northwest Regional Development Commission. 2014. Northwestern Minnesota: Roseau County history. Land of the dancing sky. 12 Jan. 2019. <http://www.visitnwmi nnesota.com/Roseauhistory.htm $>$.

Noyszewski, A.K., N.O. Anderson, A.G. Smith, D. Dalbotten, E. Ito, M. Dockry, A. Timm, and H. Pellerin. 2018. Challenges of establishing native vs. exotic status of reed canarygrass herbarium specimens. HortScience 53(9S):S189. (Abstr.).

Noyszewski, A.K., N.O. Anderson, A.G. Smith, D. Dalbotten, E. Ito, M. Dockry, A. Timm, and H. Pellerin. 2019. Challenges of establishing native versus exotic status of herbarium specimens. HortTechnology 29:549-553, doi: 10.21273/ HORTTECH04313-19.

Noyszewski, A., N.O. Anderson, A.G. Smith, A. Kilian, D. Dalbotten, E. Ito, A.
Timm, and H. Pellerin. 2020. Regional patterns of reed canarygrass (Phalaris arundinacea L.) genetic structure along six major Minnesota rivers change management strategies. Proc. Upper Midwest Inv. Species Conf. I July 2020. < https://www. umisc.net/uploads /1/0/7/5/10750703/ umisc_2020_complete_agenda_-_9-2420.pdf $>$. (Abstr.).

Noyszewski, A.K., N.O. Anderson, A.G. Smith, A. Kilian, D. Dalbotten, E. Ito, A. Timm, H. Pellerin, B. Kubátová, T. Kávová, V. Januš, V. Čurn, K.R. Edwards, D. Bastlová, and J. Květ. 2021. Riparian populations of Minnesota reed canarygrass (Phalaris arundinacea) are most likely native, based on SNPs (DArTseqLD). Wetlands Ecol. Manage. 29:467-494, doi: 10.1007/s11273-021-09795-8.

Pimentel, D., L. Lach, R. Zuniga, and D. Morrison. 2000. Environmental and economic costs of nonindigenous species in the United States. BioScience 50:53-65, doi: 10.1641/0006-3568(2000)050[0053: EAECON]2.3.CO;2.

Prairie Island Indian Community. 2021. The People of Prairie Island welcome you! 12 Mar. 2021. < http://prairieisland.org/>.

Prud'homme, L.A. 1916. Pierra Gaultier de Varennes, sieur de la Verendrye. Hist. Soc. St. Boniface Bul. 5:37.

Quintanar, A., S. Castroviejo, and P. Catalan. 2007. Phylogeny of the tribe Aveneae (Poideae, Poaceae) inferred from plastid TRNT-F and nuclear ITS sequences. Amer. J. Bot. 94:1554-1569.

Rawls, J. 1996. Political liberalism. Columbia University Press, New York, NY.

Rea, A.M. 1991. Gila river Pima dietary reconstruction. Arid Lands Nwsl. 31:3-10.

Red Lake Nation. 2019. MISKWAAGAMIIWI - ZAAGAIGANING. 12 Mar. 2021. <https://www.redlakenation.org/>.

Reinhardt Adams, C. and S.M. Galatowitsch. 2005. Phalaris arundinacea (reed canary grass): Rapid growth and growth pattern in conditions approximating newly restored wetlands. Ecoscience 12:569-573.

Ricciardi, A. and J. Cohen. 2007. The invasiveness of an introduced species does not predict its impact. Biol. Inv. 9:309-315, doi: 10.1007/s10530-0069034-4.

Richardson, D.M., P. Pyšek, M. Rejmánek, M.G. Barbour, F.D. Panetta, and C.J. West. 2000. Naturalization and invasion of alien plants: Concepts and definitions. Divers. Distrib. 6:93-107, doi: 10.1046/j.14724642.2000.00083.x.

Richardson, D.M., P. Pyšek, D. Simberloff, M.G. Rejmánek, and A.D. Mader. 2008.
Biological invasions - The widening debate. Prog. Hum. Geogr. 32:295-298, doi: $10.1177 / 0309132507088313$.

Sauer, J.D. 1988. Plant migration: The dynamics of geographic patterning in seed plant species. Univ. California Press, Berkeley, CA.

Schoth, H.A. 1938. Reed canary grass. U.S. Dept. Agr. Farmers' Bul. No. 1602.

Seed Today. 2012. Grass seed production in NW Minnesota. 30 Dec. 2020. <https:// www.seedtoday.com/article/106890/ grass-seed-production-in-nw-minnesota $>$.

Shakopee Mdewakanton Sioux (Dakota) Community. 2021. A message from the Shakopee Mdewakanton Sioux Community. 12 Mar. 2021. <https://www.shakopeeda kota.org $/>$.

Simberloff, D. 2012. Nature, natives, nativism, and management: Worldviews underlying controversies in invasion biology. Environ. Ethics 34:5-25.

Soulé, M. 1985. What is conservation biology? Bioscience 35:737-744.

Statistique Canada. 2001. Recensement de l'agriculture de 2001: donnés sur les exploitations et les exploitant agricoles. Statistique Canada, Ottawa, ON, Canada.

Steltzer, U. 1976. Indian artists at work. University of Washington Press, Seattle.

Takacs, D. 1996. The idea of biodiversity: Philosophies of paradise. Johns Hopkins Univ. Press, Baltimore, MD.

The Nature Conservancy. 2021. The Nature Conservancy in Minnesota. 12 Mar. 2021. <https://www.nature.org/en-us/ about-us/where-we-work/united-states / minnesota $/>$.

Thompson, K., J.G. Hodgson, and T.C.G. Rich. 1995. Native and alien invasive plants: More of the same? Ecography 18:390-402.

Turner, N.J., R. Bouchard, and D.I.D. Kennedy. 1980. Ethnobotany of the Okanagan-Colville Indians of British Columbia and Washington. British Columbia Provincial Museum, Victoria, BC, Canada.

University of Connecticut, Connecticut Invasive Plant Working Group. 2018. Invasive plant list. 20 June 2020. <https:// cipwg.uconn.edu/invasive_plant_list/\#>.

University of Georgia. 2021. EDDMapS: Reed canarygrass, Phalaris arundinacea L.: This species is introduced in the United States. 12 Mar. 2021. <https:// www.eddmaps.org/distribution/usstate. cfm?sub=6170 $>$.

University of Minnesota Libraries. 2021. Plant information online. 12 Mar. 2021. 
$<$ https://www.lib.umn.edu/ahl/plantinformation-online $>$.

U.S. Bureau of Land Management. 2006. The weed hall of shame. 1 Jan. 2019. <https://plants.usda.gov/java/noxious $>$.

U.S. Bureau of Land Management. n.d. Weeds and invasives. 12 Mar. 2021. <https://www.blm.gov/programs/ natural-resources/weeds-and-invasives $>$.

U.S. Congress. 1996. H.R.4283National Invasive Species Act of 1996, 104th Congress (1995-1996), 12 Mar. 2021. <https://www.congress.gov/bill/ 104th-congress/house-bill/4283 >.

U.S. Department of Agriculture, Animal and Plant Health Inspection Service. 2010. Federal noxious weed list. 10 Mar. 2021. <https://www.aphis.usda.gov/plant health/plant_pest_info/weeds/down loads/weedlist.pdf $>$.

U.S. Department of Agriculture, Animal and Plant Health Inspection Service. 2020. Invasive species. 12 Jan. 2019. <https:// www.aphis.usda.gov/aphis/ourfocus/wild lifedamage/operational-activities/sa_ invasive/ct_invasive_speciesl $>$.

U.S. Department of Agriculture, National Invasive Species Information Center. n.d. National Invasive Species Information Center (NISIC): The gateway to invasive species information; covering federal, state, local and international sources. 12 Mar. 2021. <http://invasivespeciesinfo.gov/>.

U.S. Department of Agriculture, Natural Resources Conservation Service. 2002. Reed canarygrass. Phalaris arundinacea L. Plant Symbol = PHAR3. $<$ https: $/ /$ plants. usda.gov/plantguide/pdf/pg_phar3.pdf $>$.

U.S. Department of Defense. 2019. Invasive species. 12 Mar. 2021. <https:// www.denix.osd.mil/nr/focus-areas / invasivespecies/index.html>.

U.S. Department of the Navy. U.S. Army Corps of Engineers. 2009. U.S. Army Corps of Engineers invasive species policy. 12 Mar. 2021. <https://www.nae.usace. army.mil/Portals/74/docs/regulatory/ InvasiveSpecies/policy.pdf $>$.
U.S. Department of Transportation. Federal Highway Commission. n.d. Environmental review kit. 12 Mar. 2021. <https://www. environment.fhwa.dot.gov/ecb/glossary_ disc.aspx $>$.

U.S. Fish and Wildlife Service. 2012. Nation marks Lacey Act centennial, 100 years of federal wildlife law enforcement. 7 July 2021. <https://www.fws.gov/ pacific/news/2000/2000-98.htm $>$.

U.S. Fish and Wildlife Service. 2015. Invasive species. 12 Jan. 2019. < http:// invasives.fws.gov/ $>$.

U.S. National Plant Board. 2014. NPB National Plant Board. 12 Mar. 2021. $<$ http://nationalplantboard.org/>.

Upper Sioux Community. 2021. Upper Sioux Community, Pejuhutazizi Oyate. 12 Mar. 2021. <http://www.uppersioux community-nsn.gov $/>$.

Vila, M., E. Weber, and C.M.D. Antonio. 2000. Conservation implications of invasion by plant hybridization. Biol. Inv. 2:207217, doi: 10.1023/A:1010003603310.

Voshell, S.M., R. Baldini, R. Kumar, N. Tatalovich, and K.W. Hilu. 2011. Canary grasses (Phalaris, Poaceae): Molecular phylogenetics, polyploidy and floret evolution. Taxon 60:1306-1316, doi: 10.1002/tax.605007.

Voshell, S.M. and K.W. Hilu. 2014. Canary grasses (I, Poaceae): Biogeography, molecular dating and the role of floret structure in dispersal. Mol. Ecol. 23:212-224.

Voshell, S.M., R. Baldini, and K.W. Hilu. 2015. Infrageneric treatment of Phalaris (canary grasses, Poaceae) based on molecular phylogenetics and floret structure. Aust. Syst. Bot. 28:355-367.

Vymazal, J. 2001. Constructed wetlands for wastewater treatment in the Czech Republic. Water Sci. Technol. 44:369-374.

Vymazal, J. 2013. Vegetation development in subsurface flow constructed wetlands in the Czech Republic. Ecol. Eng. 61:575-581.
Warren, C.R. 2007. Perspectives on the "alien" versus "native" species debate: A critique of concepts, language and practice. Prog. Hum. Geogr. 31:427-446, doi: 10.1177/ 0309132507079499.

Washington State Noxious Weed Control Board. 1995. Reed canarygrass (Phalaris arundinacea). 20 June 2020. <https://www. nwcb.wa.gov/weeds/reed-canarygrass $>$.

Weatherfield, J. 1989. Indian givers: How the Indians of the Americas transformed the world. Fawcett Columbine, New York, NY.

White Earth Nation. 2021. White Earth Nation welcomes you! 12 Mar. 2021. $<$ https://whiteearth.com/home $>$.

Whitney, K.D. and C.A. Gabler. 2008. Rapid evolution in introduced species, 'invasive traits' and recipient communities: Challenges for predicting invasive potential. Divers. Distrib. 14:569-580, doi: 10.1111/j.1472-4642.2008.00473.x.

Williamson, M. 1996. Biological invasions. Chapman and Hall, London, UK.

Williamson, M. and A. Fitter. 1996. The varying success of invaders. Ecology 77 : 1661-1666.

Wilson, H. 1863. The chronicles of a garden: Its pets and its pleasures. James Nisbet, London, UK.

Xiong, Y., Y. Xiong, S. Jia, and X. Ma. 2020. The complete chloroplast genome sequencing and comparative analysis of reed canary grass (Phalaris arundinacea) and hardinggrass ( $P$. aquatica). Plants 9:748, doi: 10.3390/plants9060748.

Zedler, J.B. and S. Kercher. 2004. Causes and consequences of invasive plants in wetlands: Opportunities, opportunists, and outcomes. Crit. Rev. Plant Sci. 23:431-452.

Zedler, J.B. and S. Kercher. 2005. Wetland resources: Status, trends, ecosystem services, and restorability. Annu. Rev. Environ. Resour. 15(30):39-74, doi: 10.1146/annurev.energy.30.050504.re3, j14424. 